\title{
The 1982 Horizontal Merger Guidelines: Of Collusion, Efficiency, and Failure
}

\author{
Thomas E. Kauper $\dagger$
}

The release in 1982 by the Department of Justice of its new merger Guidelines was, in one sense, long overdue. Whether analyzed in terms of economic rationality, or looked to as an accurate guide to the thinking of the Department, the old 1968 Guidelines ${ }^{1}$ needed to be changed. They were out of touch with inodern economic thinking about mergers, and in a number of respects failed to reflect Department enforcement pohicy accurately. Almost imevitably, they were also imconsistent, im some respects, with judicial developments in the intervening fourteen years. To be sure, the Department followed through 1980 an enforcement policy with respect to horizontal mergers that relatively closely tracked the "numbers" set out in the 1968 Guidelines. And the courts have not deviated substantially from the basic horizontal merger "rules" formulated by the time the earlier Guidelines were issued. ${ }^{2}$ But any resemblance between the 1968 Guidelines as to vertical mergers and actual enforcement practice has always been more imagined than real. $^{3}$ Moreover, the conglomerate merger Guidelines, which mani-

$\dagger$ Professor of Law, University of Michigan Law School. A.B. 1957, J.D. 1960, University of Michigan. I am grateful for the helpful comments of my colleague, Joseph F. Brodley, and for the assistance of Mary Snapp, a second year studeut at the University of Michigan Law School.

1. U.S. Dep't of Justice, Merger Guidelines-1968 (May 30, 1968), reprinted in 2 TRADE REG. REP. (CCH) If 4510 (1982) [heremafter cited as 1968 Guidelines].

2. The basic approach to horizontal mergers has been reliance on a presumption of anticompetitive effect based upon concentration and market share data, with some emphasis on a trend toward concentration. The presumption can be rebutted by establishment of the failing company defense, but not by the proof of efficiencies. As a general rule, few mergers have been held lawful because entry barriers were shown to be low. These general principles, established in United States v. Philadelphia Nat'l Bank, 374 U.S. 321 (1963); United States v. Aluminum Co. of Am. (Rome Cable), 377 U.S. 271 (1964); FTC v. Procter \& Gamble Co., 386 U.S. 568 (1967), continue to guide lower courts to date. Arguably, the Supreme Court has never authoritatively rejected an efficiencies defense. See, e.g., 4 P. AREeda \& D. TURNer, ANTitrust Law I 941b, at 153-54 (1980). But the Court lias never recognized that proof of efficiencies would justify an otherwise anticompetitive merger. Whether United States v. General Dynamics Corp., 415 U.S. 486 (1974) marks a significant departure from the approach of earlier cases is a matter of debate. In General Dynamics, the Court recognized the legitimacy of presumptive rules based on structural data, but made clear that the presumption could be rebutted by proof that aggregated market shares overstated the competitive impact of the merger. In my mind General Dynamics is consistent with the 1968 Guidelines.

3. This statement refiects my own experience, and simple statistics. See 4 P. AREEDA \& D. 
fested a vagueness consistent with the few relevant judicial rulings accumulated by 1968, were hardly guidelines at all. They were sufficiently broad to permit, and simultaneously failed to reflect, wide swings in enforceinent pohcy. ${ }^{4}$ Neither were they consistent with the restrictive judicial pronounceinents which led, by the mid-1970's, to the view often recited by enforcenent officials that section 7 of the Clayton Act offered little basis for attacking most conglomerate mergers. ${ }^{5}$

If enforcement guidelines are to exist at all, and I am not certam that they should, they inust meet at least three criteria. They should reflect actual practice. They should make sense, reflectimg an intelligent policy with respect to merger control. And they should guide. By 1982, the 1968 guidelines failed to satisfy any of these standards. They were sorely im need of revision.

If the release of the new Guidelines was thus overdue, their timing was right in a different sense. The 1968 Guidelines were carefully drawn to incorporate the economic thinking of the time, and did so successfully, althouglh the Antitrust Division tempered the teaching of economics to reflect the Division's "law enforcement"6 philosophy to a greater degree than do the new Guidelines. While the imtervening years have brought steadily mounting criticism, it has only been in the past several years that a significant new economic consensus has einerged-a consensus that new Guidelines could substantially incorporate. This consensus is far froin complete, but is sufficiently developed to provide assurance that a significant relaxation of the 1968 rules

TURNER, supra note 2, I 1020, at 298-309, listing significant vertical merger cases of the past twenty-odd years. Of the 34 cases listed, only one was a straightforward vertical case brought by the Department after the 1968 Guidelines were issued.

4. In 1969, then Assistant Attorney General Richard McLaren filed a number of cases challenging large conglomerate mergers on a variety of grounds, including increases in so-called "aggregate concentration" (concentration in total manufacturing assets). McLaren warned that he was prepared to go beyond the Guidelines in the latter respect. Hearings on the Subject of Tax Reform Before the House Comm on Ways and Means, 91 st Cong., Ist Sess. 2368 (1969) (statement of Richard W. McLaren, Ass't Att'y Gen., Antitrust Div., Dep't of Justice), reprinted in 5 TRADE REG. REP. (CCH) I 50,101 (Jan. 17, 1972).

These attacks were unsuccessful. See, e.g., United States v. ITT, 324 F. Supp. 19 (D. Conn. 1970). By 1972, however, the government's challenges to conglomerate mergers were confined to cases involving potential competitors. And by 1977 , after a series of restrictive judicial decisions, the Department advised that it would no longer bring some cases which appeared to be within the 1968 conglomerate Merger Guidelines. Donald 1. Baker, Ass't Att'y Gen., Antitrust Div., Dep't of Justice, Address before the Southwestern Legal Foundation, Government Litigation Under Section 7: The Old Guidelines and the New Antitrust Majority (Feb. 24, 1977) (Justice Dep't release).

5. E.g., Mergers and Economic Concentration: Hearings on S.600 Before the Senate Comm. on the Judiciary, 96th Cong., 1st Sess. 61-62 (1979) (Stateinent of John H. Slenefield, Ass't Att'y Gen., Antitrust Div., Dep't of Justice). 1 (1978).

6. See generally Kauper, Competition Policy and the Institutions of Antitrust, 23 S.D.L. REv. 
was both warranted and necessary. Changes in economic thought dictate changes in enforcement policy. Also, the new consensus eased the institutional difficulties of changing the public statements in which that policy was set forth.

The 1968 merger Guidelines were, inter alia, a symbol of commitment to a particular philosophy about the relationship of government to corporate enterprise. Up to now, this "political" context made difficult what appears to be a weakening of the Guidelines. But by 1982 the climate was right. The fact that few, if any, responsible economists cared to defend the 1968 Guidelines eased the way for change. And the political climate was already prepared to tolerate a more lenient attitude toward mergers. With American firms no longer thought to be competitive in world markets, high unemployment attributed to import intrusion, and an economy generally in a prolonged period of stagnation, merger policy-and antitrust enforcenent in general-has become one of a number of scapegoats. Whether right or wrong, this is hardly surprising. One of the hallmarks of antitrust enforcement has been our willingness to correct its excesses only in times of stress. Indeed, enforcement lias been abandoned altogether in periods of national crisis. ${ }^{7}$ When nrost economists agreed that the old liorizontal Merger Guidelines (and, more importantly, the judicial "rules" they partially incorporated) were competitively unnecessary and actually impaired efficiency, relaxation of the standards conld be seen as a step in the direction of better times. Change in the symbol of governmental commitment to a relatively severe merger policy-the 1968 Guidelines-became a pohtical nonevent. The most striking aspect of the political response to the 1982 Guidelines lias been its virtual absence. 'Criticism has come from the business community and antitrust bar, the very groups who might lave been expected to welcome the 1982 Guidelines. The emphasis of their criticism has been upon the Guidelines' complexity and lack of clarity. Part of the purpose of this Article is to respond to these complamts.

In Part I, I offer some observations on what guidelines should do, how they sliould be evaluated, and why a substantial degree of complexity and uncertainty cannot be avoided. Part II focuses on the Guidelines' treatment of the critical tradeoff between the adverse effects of collusion and the benefits of increased firm efficiency. In Part III, I examine tlie failing company defense. After examining these substantive issues in light of the purposes the Guidelines are intended to serve, I conclude that, on balance, complaints about the Guidelines'

7. This was most clearly true during the Depression of the 1930's. See R. PosNer \& F. Easterbrook, AntrTrust 126-27 (2d ed. 1981); A. Neale, The ANTITrust Laws of the U.S.A. 9 (N.I.E.S.R. 2d ed. 1970). 
lack of clarity are unwarranted because simpler alternatives are substantively inferior.

\section{Of Guidelines in General}

What are guidelines? How can they best accomplish the purposes they are meant to serve? And by what standards should they be evaluated? Answers to these questions are elusive, but consideration of the new Guidelines and the controversy over their complexity cannot proceed without them. Therefore, I begin with these questions.

Enforcement guidelines were born im part out of the persistent quest of the busmess community and bar for certamty. The 1982 Guidelines have been criticized for adding silt to already muddy waters $^{8}$ and for their failure to satisfy a single-minded certainty standard. Indeed, little of the criticisin lias been directed toward the substantive policies they reflect. One might easily get the impression that if the Division's policies are complex, we would prefer that it be quiet about them-that is, no guidelines would be better than complex ones.

One of the persistent dilemmas of antitrust is that simple rules are proclaimed to be irrational, while rational, more complex policies are criticized for their want of simplicity. The analysis in Von's Grocery, for example, has been criticized, indeed ridiculed, on substantive grounds. ${ }^{9}$ But no one can deny that an antitrust policy based on Von's Grocery would be simple to follow. Similarly, the per se rule applied to vertical territorial and customer restrictions in Schwinn ${ }^{10}$ was clear, albeit misguided. But to urge that Schwinn be overruled and then condemn the result on certainty grounds hardly seems appropriate. At soine point, we must recognize that the price of rationality is complexity. Only if the same degree of rationality can be achieved with greater simplicity is the criticism of doctrine on certainty grounds at all legitimate.

But enforceinent guidelines are not doctrine. Doctrine must develop in some fashion, precise or imprecise, if cases are to be decided. Guidelines, however, need not be issued. They do not serve the parochial enforcement interests of the Justice Department, except to instruct trial staffs-a function easily performed by an internal staff memoran-

8. See, e.g., Sims, New Merger Guidelines Provide No Real Surprises, Legal Times (Washington), June 21,1982 , at 17 , col. 1 .

9. United States v. Von's Grocery Co., 384 U.S. 270 (1966). For the most severe criticism, see R. Posner, Antitrust Law 105-09 (1976); R. Bork, The Antitrust Paradox 217-18 (1978).

10. United States v. Arnold, Schwinn \& Co., 388 U.S. 365 (1967), overruled in Continental T.V., Inc. v. GTE Sylvania Inc., 433 U.S. 36 (1977). 
dum. The Department knows merger cases are complex, that the ideal data are often not available, and that no two cases are alike. It is clearly not in the Department's imterests to say too much, thus limiting its prosecutorial discretion. The normal inclination, then, is not to issue guidelines. The Department presumably does so, not out of some philosophical commitment to open government, but because guidelines promote efficiency by facilitating corporate planning and reducing the risks of error, and, more importantly, because its limited resources make a high degree of voluntary comphance essential. These goals are only met by guidelines which are relatively specific.

But any enforcement guidelines, however precise, will necessarily fail to satisfy the ultimate certainty test, i.e., the ability to rely on them with confidence. Their utility is necessarily limited because private litigants, the Federal Trade Commission, and, ultimately, the courts may apply different standards. One could labor for weeks over HerfindahlHirschman Index (HHI) calculations, hypothetical 5\% price increases, and a variety of other factors recited im the 1982 Guidelines only to discover that the FTC will conduct the investigation. No Guidelines set forth the division of labor between the Commission and the Department. " Worse yet, after convincing the Department, under its Guidelines, not to challenge a given transaction, the merging parties may still end up in court if a private party files suit before a judge who finds the Guidelines confusing or irrelevant.

Antitrust lawyers understand these difficulties. Many busmessmen do not. Some in the busmess community have criticized the new Guidelines (as well as the old) because they fail to assure the security of transactions which satisfy the Guidelines' standards. But the Department ought not be faulted for failing to do that which it cannot, even though these institutional factors alone suggest that guidelines may become a snare for the unwary.

An evaluation of particular guidelines, however, must further con-

11. On June 14, 1982, the date of issuance of the new Guidelines by the Department, the Commission issued its own Statement Concerning Horizontal Mergers to explain its view of the 1982 Department Guidelines. See FTC, Statement Concerning Horizontal Mergers (June 14, 1982), reprinted in TRADE REg. REP. (CCH) No. 546, at 71 (June 16, 1982) (special supplement to 2 Trade Reg. Rep. (CCH) I 4225 (Aug. 9, 1982) [hereinafter cited as FTC Statement]. It does not address non-horizontal mergers. Nor does it deal with issues of market definition. While the Statement does indicate that the Commission and its staff will give the Department's Guidelines "considerable weight," it varies somewhat from them. The FTC Statement indicates that the Commission will continue to rely on market share and concentration data (at higher threshold Ievels than the 1968 Department Guidelines), but in conjunction with a variety of other factors, including ease of entry, the presence of technological change in the market, the condition of the merging firms, and ease of collusion. The FTC's position on these issues is even more flexibly stated than that of the Department. The FTC statement differs with respect to efficiencies and the failing company defense, as discussed subsequently. 
sider the goals they are intended to serve. The Department describes the Guidelines as a statement of its own enforcennent intentions-leaving the impression that they may be significantly different than the standards applied by the courts. This impression is fortified by the assertion that the Guidelines do not necessarily indicate "how [the Department] will conduct the litigation of cases it decides to bring." 12 This description is technically correct, smce the Department lacks authority to do anything else. When the Guidelines are viewed in this limited fashion, the issues raised in evaluating them relate only to the appropriate exercise of prosecutorial discretion. That is, the Guidelines should then be analyzed more in teruns of resource use than of nonnative standards: the question is which mergers to challenge, rather than the legal doctrine to be used in determining illegahty. The significance of the Guidelines' inerger policy is thus limited. Since the operative norms remain only in the hands of the courts, whose processes are available to aggrieved private parties, the Guidelines are subject to a corrective mechanism where they go too far, or do not go far enough. The degree to which the Guidelines are workable, an issue of some consequence, should be addressed in terms of the Department's inforinal processes, rather than those of the courtroom, recognizing that the Department is able to gather, assimilate, and evaluate data in a way that formal courtroom procedures do not permit.

The "prosecutorial discretion" characterization of the Guidelines not only emphasizes the insecurity of corporate planning based solely upon them, but also invites consideration of the appropriate role of prosecutorial discretion in antitrust. If the Guidelines' standards do not conform to those formulated by the courts, they pose an obvious institutional question: how far is the Department, charged with the President's duty faithfully to execute the law, free to depart from judicial standards developed under a general statutory directive (in this instance section 7 of the Clayton Act)? ${ }^{13}$ This issue has been raised with respect to the antitrust enforcement program of the current administration, not only with respect to inerger enforcement policy, but in connection with other issues as well. ${ }^{14}$ It will not be resolved here. But antitrust is not like some other criminal law enforcement programs, where issues related to prosecutorial discretion are more commonly discussed. Because antitrust's statutory directives are extremely broad, specific "rules" are judge-made in cases which rest on complex facts.

12. U.S. Dep't of Justice, Merger Guidelines § I, 47 Fed. Reg. 28,493, 28,494 (1982), reprinted in 71 CALIF. L. REv. 649, 649 (1983) [hereinafter cited without cross-reference as Guidelines].

13. See generally Kauper, supra note 6.

14. See, eg., Kramer, Antitrust Today: The Baxterization of the Sherman and Clayton Acts, 1981 WIS. L. REV. 1287. 
For this and a variety of other reasons, prior decisions are virtually never overruled, even though it is clear they would not be decided the same way today. "The law" is not determined simply by reading a statute or relying upon every case which has not been overruled.

The new Merger Guidelines do reflect an enforcement policy which differs substantially from standards set forth in soine of the merger cases of the 1960's. But more extreme Supreme Court decisions, such as those in Von's Grocery and Brown Shoe, ${ }^{15}$ have been so substantially undermined by subsequent decisions that it is hard to imagime the same outcomes today. ${ }^{16}$ Moreover, the economic analysis utilized in decisions of that period no longer commands the consensus that it did then. ${ }^{17}$ Where the only statutory criterion for identifying illegal transactions is a likely effect on competition, is the Department not entitled (and even perhaps required) to utilize contemporary economic thinking, ratler than that of two decades past? While I do not suggest that the new Guidelines are consistent im all respects with contemporary legal standards, the degree of mconsistency ought not be measured against those past decisions which are in no real sense "the law" today.

In any event, seeing the Guidelines in simple terms of prosecutorial discretion ignores some of their effects. Clearly, enforcement guidelines, and the Merger Guidelines im particular, are more than a public statement about case selection-a kind of exposé of the internal workings of the Department. They also function, in part, as a form of economic regulation, not because they are "rules" in the classic, judicial sense, but because they are often outcome determinative. And they are intended to be. The so-called "safe harbor" provision im

15. Brown Shoe Co. v. United States, 370 U.S. 294 (1962).

16. These and similar cases have never been overruled. But Brown Shoe's reliance on noneconomic values has been undercut by the efficiency-oriented approach of cases like Continental T.V., Inc. v. GTE Sylvania Inc., 433 U.S. 36, 53 n.21 (1977). Although not a merger case, the efficiency analysis in Sylvania is based upon a view of vertical restraints and integration not consistent with the analysis in Brown Shoe. Most observers would agree that the court in Brown Shoe "invalidated a rather slight and unimportant merger in a rather competitive industry on the basis of a modest increase in concentration, if any." L. Sullivan, HANDBOOK OF THE LAW OF ANTITRUST 594 (1977).

17. United States v. Philadelphia Nat'l Bank, 374 U.S. 321 (1963); United States v. Aluninuin Co. of Am. (Rome Cable), 377 U.S. 271 (1964), and a number of other decisions of the 1960's rested on the commonly held view that there was a necessary correlation between lighly concentrated market structures and poor market performance, achieved either through overt collusion or interdependent pricing. More recent studies fail to confirm sucl a necessary correlation, although the issue is not yet finally resolved. See Edwards, Joffe, Kolasky, McGowan, Mendez-Penate, Ordover, Proger, Solomon \& Toepke, Proposed Revisions of the Justice Department's Merger Guidelines, 81 Colum. L. Rev. 1543, 1550-51 (1981); P. Pautler, A Review of the Economic Basis for Broad-Based Horizontal Merger Policy (Oct. 1981) (unpublislied manuscript). For an exhaustive treatment of the subject, see Y. Brozen, Concentration, Mergers, and Public Policy (1982). 
the horizontal merger Guidelines, which indicates that the Department is "unlikely to challenge" mergers where the postmerger HHI is below 1000 , is intended to permit, if not encourage, mergers of relatively small size. Similarly, the Guidelines' assertion that the Department "is likely to challenge" mergers where the HHI is above 1800 and the imcrease brought about by the merger is 100 or more should, and is intended to, deter acquisitions of that size. Again, the Guidelines alone may not be determinative. Whether these minimum and maximum standards have the intended deterrent effect will depend, in part, on their conformity to judicial standards. If the "safe harbor" provision is considerably inore expansive than contemporary court rulings, unergers within the "harbor" may still be deterred by the possibility of private hitigation. ${ }^{18}$ If, on the other hand, the maximum standard is too restrictive measured against current case law, the parties may merge and force the Department to litigate. But most firms do not want to buy lawsuits. The cost and uncertainties imposed by such litigation give the Guidelines a direct deterrent effect, just as do other legal "rules."

The Guidelines have a clear normative effect in some cases. They also more subtly influence the development of doctrime, both because courts have been influenced by the Guidelines and because the Department is likely to urge that the positions it has so carefully formulated should be the law. The Guidelines are a blueprint for the Division's efforts to reshape the imterpretation of section 7 , through its own hitigation or through participation in hitigation imitiated by others.

In sum, enforceinent guidelines must be evaluated at several different levels. Are they a legitimate exercise of prosecutorial discretion, whatever the substantive standards applied by the courts? Are they workable at the Department level? Do the Guidelines refiect a rational inerger policy, to be apphied not only by the Departinent but by the courts as well? Would they be workable in the courtroom? Will they, and should they, become the vehicle for major reforin of substantive legal standards?

With these questions im mind, I turn to the substance of the new horizontal merger Guidelines. But I do so recognizing that complexity is neither necessarily bad, nor totally avoidable. Nor is there a single litmus test by which guidelines can be declared successful.

18. The Department may seek to intervene or otherwise present its views, presumably those stated in the Guidelines, in such cases. The effect could be to reduce the utility of private litigation as an independent deterrent if and when judicial standards conform to the Guidelines. 
II

\section{The 1982 Horizontal Merger Guidelines-OF COLLUSION AND EFFICIENCY}

\section{A. The Old Guidelines Compared with the New}

Consideration of the 1982 horizontal merger Guidelines, and of the critical issues related to the likelihood of collusion and possible effciencies resultimg from a proposed merger that are the focus of this Part, must begim with a comparison of the old and the new Guidelines.

It cannot be demed that the 1982 Merger Guidelines differ significantly from those issued in 1968 and, to a lesser extent, from current judicial standards. At a bare minimum, they symbolize a more favorable attitude toward mergers. This general impression may be of greater consequence over the long run than the Guidelines' actual provisions. In symbolic terms, it is the change from the earlier Guidelines that is important. But in practical terms, much of the change has been evolutionary - the result of a continumg interplay between the courts, public enforcement agencies, and private litigants. The 1982 Guidelines as a whole adopt existing standards as much as they announce major departures from them.

While most dramatic with respect to vertical mergers, changes from the earher Guidelines permeate the new throughout. If nothing else, the new approach to market definition, discussed elsewhere in this Symposium, ${ }^{19}$ assures that this is so. A new language of economic analysis must be learned. Yet, superficially, the most striking aspect of the new horizontal merger Guidelines is their similarity to the earlier Guidelines, rather than the differences between them.

The most important similarity is the new Guidelines' approach to the correlation between market strncture and likely collusion among firms. Like the earlier Guidelines, the 1982 horizontal merger Guidelines rely on presumptive rules based upon numerical measures of market concentration and structure. Although this approach was expected, particularly given its continued use by the judiciary, its validity is not a self-evident proposition. From their inception, such rules have been predicated upon some theoretical or demonstrable colmection between a defined market structure (other than single firm monopoly) and market power. The 1982 Guidelines contimue to rely upon the existence of such a coimection, asserting that "[w] here only a few firms account for most of the sales of a product, those firms can in some circumstances coordmate, exphicitly or imphicitly, their actions in order to approxi-

19. See Harris \& Jorde, Market Definition in the Merger Guidelines: Implications for Antitrust Enforcement, 71 CALIF. L. Rev. 464 (1982). 
mate the performance of a monopolist."20 Because mergers in highly concentrated markets may enhance the likelihood of collusion, they are presumptively suspect. The Guidelines address the prevention of collusion, a policy consistent with section 7's prophylactic purposes, by attempting to define the "circumstances" in which collusion is likely to occur.

A fundamental issue arises here from the very outset, for some contend that there is no correlation between concentration, however defined, and such measures of market power as persistently high profits; ${ }^{21}$ therefore the 1982 Guidelines rest on the same faulty premise as those of 1968. The new Guidelines may be particularly vulnerable to this attack, smce the Department lumps explicit and implicit collusion together with no explanation as to how the latter occurs. But inuch as we might like to know the Department's thinking about "imiphicit" collusion, the point is academic with respect to the Guidelines unless the circumstances in which explicit collusion is most likely to occur without detection vary significantly from those in wlich implicit collusion will, if ever, occur. This is not likely to be so. Moreover, a merger policy directed solely toward explicit collusion is rational and consistent with section $7 .^{22}$

Since the 1982 Guidelines rely upon presumptive rules drawn from market structure, they follow the basic pattern of the 1968 Guidelines in other respects. Simce structural rules require that markets be defined, guidelines must therefore speak to the methodology of doing so. A numerical measure of concentration and firm size must be set forth. Because the rules are presumptive, justifications for inergers become defenses, and the burden of proof is placed upon the merging parties. Given the extraordmary difficulties of proving such a justification-whether in terms of efficiencies, threatened firm failure, or otherwise-the placing of this burden is critical, both in the courtrooin and before the Department as well.

Finally, the Guidelines deal with the specific defenses to be recognized. Tradeoffs between structural rules and defenses based upon considerations of firm failure or efficiency are at the heart of a presumptive rule approach. The fundamental approach to these tradeoffs is the same in both sets of Guidelines: the Department declines im most cases to consider efficiencies related to specific transactions as a de-

20. Guidelines \& I, 47 Fed. Reg. at 28,494, 71 CALIF. L. REv. at 650.

21. See, e.g., Y. BROZEN, supra note 17. Robert Bork, relying on the view that noncollusive oligopolistic behavior (which he doubts actually exists) would rarely result in output restrictions, suggests a merger policy designed to preserve two firms of roughly equal size. "[M]ergers up to 60 or 70 per cent of the market should be permitted . . ." R. BORK, supra note 9, at 221.

22. See 4 P. AREEDA \& D. TURNER, supra note 2 , \ 910b, at 55-56. 
fense, and, in similar terms, narrowly confines its willingness to consider the failing coinpany defense. These defenses, and their relation to the collusion issue, will be discussed in more detail subsequently.

Despite these similarities in basic approach, a number of horizontal inergers that would have been challenged under the old Guidelines will not be challenged today, as the new Guidelines stand. Nor do the new Guidelines follow contemporary judicial rulings as closely as the 1968 Guidelines did, even though the latter did not extend enforcement policy to the outer limits established by the court decisions of the late 1960 's. ${ }^{23}$ Several factors contribute to this conclusion. First, the market definition process set forth in the new Guidelines will result in expanded markets and reduced market shares in most instances. Second, the use of the HHI as the measure of concentration einphasizes markets with significant disparities in firm size, and will immunize from challenge inergers in inarkets comprised of relatively equally sized firms, even where concentration is at high levels. Third, the threshold level below which mergers are relatively secure from challenge is well above that of the old Guidelines, and a number of court decisions as well. ${ }^{24}$ Fourth, the standards to be applied when concentration levels (in HHI terms) are above the "safe harbor" level are flexible enough to permit a variety of other acquisitions. These points are examined in more detail below. But first, I offer several observations and some tentative conclusions.

To begin with, the new lorizontal inerger Guidelines are hardly to be condemned because they are inore permissive than their predecessors; change was needed for the following reasons. First, and most important, preventing inergers at the lower levels of the 1968 Guidelines is now virtually conceded to be competitively unnecessary, and likely to impair efficiency. ${ }^{25}$ Second, because in recent years the courts have been influenced by these changes in economic thinking, conformity to contemporary judicial developments requires comparable changes in

23. In United States v. Pabst Brewing Co., 384 U.S. 546, 550-52 (1966), the Court was apparently prepared to find a violation based upon a showing that the aggregated nuarket share was 4.5\% (although it also relied on other nuarkets with higher aggregated shares). And in Von's Grocery, 384 U.S. at 272 , the aggregated inarket share rehed upon was $7.5 \%$ (8.9\% at the time of the inerger). Whatever one thinks of these decisions, it is clear that the Department's 1968 horizontal Merger Guidelines did not reflect these numbers; the initial threshold for such inarkets was an aggregated share of $10 \%$. Similarly, a violation was found in Brown Shoe Co. v. United States, 370 U.S. 294, 298 (1962) (predominantly a vertical nuerger case) based upon acquisition of a retailer with a $1 \%$ inarket share although the 1968 vertical Merger Guidelines used a figure of $6 \%$.

24. See infra note 32 .

25. See 4 P. AREedA \& D. TuRner, supra note 2, \ 911, at 60-67. Donald Turner, Assistant Attorney General in charge of the Antitrust Division when the 1968 Guidelines were issued, does not defend the lowest threshold levels they recite, since, without an efficiencies defense, they may allow efficiency-creating mergers to be challenged. 
enforcement policy. Third, if enforcement policies are significantly altered, guidelines slould accurately reflect them or be withdrawn. The 1982 lorizontal merger Guidelines embody a rational, albeit complex, enforcement policy which conforms, for the most part, to actual practice and sound economic analysis. While the Guidelines categorically reject the mclusion of noneconomic factors in formulating merger policy, reliance on economic analysis alone is consistent with the current trend in judicial doctrime. ${ }^{26}$

Unfortunately, the complexity of the new standards (which I believe accurately reflect the current thinking of the Department) limits their utility to those seeking guidance in evaluating and shaping merger transactions. This is in part a matter of style. The new Guidelines read, in places, more like a chapter in an industrial organization economics treatise than a simple set of guiding principles. But the complexity is also attributable to the Department's consideration of a long list of factors in addition to concentration data. The search for economic rationality las led the Department to eschew relatively simple propositions. The result is unavoidable: as already noted, the price of rationality is coinplexity.

The corollary of this lack of guidance is that the Department has retained a considerably wider range of prosecutorial discretion than it had under the 1968 Guidelines. The degree of discretion reserved is revealed by the tentative language used throughout the Guidelines, as well as by the variety of virtually unweighted factors that are to be considered in assessing competitive impact. The wide range of discretion nay be costly. In addition to making enforcement decisions diffcult to predict, the degree of discretion retamed exposes the Department to the risk of more intervention in its decisionmaking processes by other government agencies, congressional staffs, and outside parties. Public statements of "law enforcement" policy tend to deter such intervention, since deviation from such statements invites public criticism. If the Guidelines are not seen as sucl statements, and if the Department is therefore perceived as inaking nothing more than ad loc economic policy judginents that need not conform to definable

26. The debate over the legitimate goals of antitrust is of long standing, but the ascendant view is that antitrust's sole concern is economic efficiency. See, e.g., Continental T.V., Inc. v. GTE Sylvania Inc., 433 U.S. 36 (1977). The legislative history of $\$ 7$ mdicates a concern for the political and social impact of significant mergers, but may be read as using the protection of political and social values as an additional reason for prohibiting mergers which have adverse economic effects. See 4 P. AREEDA \& D. TuRNER, supra note 2, \ 904, at 11-14. The Court in Brown Shoe did appear to place independent reliance on such factors. With the exception of Von's Grocery, more recent Supreme Court decisions have not done so. But the controversy is not over; lower courts from time to time still give weight to noneconomic factors. See, e.g., Mercantile Tex. Corp. v. Board of Governors of the Fed. Reserve Sys., 638 F.2d 1255 (5th Cir. 1981). 
standards, otliers holding contrary economic policy views may feel nore free to interject themselves into the Department's decisionmaking. The Department's "law enforcement" shield, in the form of Guidelines, will then afford less protection to its internal processes than did the earlier Guidelines. ${ }^{27}$

Similarly, the wider the range of discretion reserved, and the greater the number of variables imvolved, the more likely are the parties to seek informal guidance from, and attempt to negotiate their transaction through, the Department. Guidelines that are inflexible offer little range for such negotiation. Under the highly flexible 1982 Guidelines, negotiations designed to avoid the filing of a complamt, or to work out in advance the boundaries of relief, will becone more comnon. This will place the Departinent itself $m$ the position of determining the ultimate contours of particular transactions such that it will assume a direct regulatory role. Such negotiated arrangements may have unfortunate consequences, since the Department may have insufficient knowledge to assure the correctness of the negotiated outcome. Moreover, the most common result of such negotiations is cannibalization of one of the merging parties. While this assures that the parts of the inerging coinpanies posing the most severe competitive problems are removed from the transaction, such hastily arranged transactions provide little assurance that the transferred assets will be viable outside the larger entity of which they were previously a part.

Finally, given the complexity of the standards governing mergers that are neither presumptively allowed nor presumptively outlawed, the time during which the Hart-Scott-Rodino Antitrust Improvement Act ${ }^{28}$ stays consummation of the transaction is likely to be madequate to permit the Department to obtain and evaluate all of the data it needs. So-called "second requests" will be commonplace. There will be less einphasis on the use of preliminary injunctions. More cases will likely be brought after consummation of the transaction, when divestiture, which is often neither efficient nor effective, ${ }^{29}$ will be the only available remedy.

Some of the tentative conclusions set out above may prove to be

27. See Kauper, supra note 6.

28. Clayton Act $\S 7$ A, Pub. L. No. 94-435, $\$ 201,90$ Stat. 1390 (1976) (codified at 15 U.S.C. $\S 18 \mathrm{a}(1976)$ ), requires advance notification to enforcement agencies for mergers over specified sizes. Consummation is automatically stayed for 30 days after notification (15 days in the case of a tender offer) and may be extended an additional 20 days ( 10 days for a tender offer) if the agency requests additional information.

29. See The Antitrust Improvements Act of 1975: Hearings on S. 1284 Before the Subcomm. on Antitrust and Monopoly of the Scnate Comm. on the Judiciary, 94th Cong., 1st Sess. 90, 96-99 (1975) (statement of Thomas E. Kauper); Easterbrook \& Fischel, Antitrust Suits by Targets of Tender Offers, 80 Mich. L. Rev. 1155, 1163 (1982); Elzinga, The Antimerger Law: Pyrrhic Victories?, 12 J.L. \& EcoN. 43 (1969). 
wrong; they are, after all, only educated guesses. Not all of these consequences are necessarily bad. And soine are the inevitable results of avoiding overly simplistic rules. In my judgment, the Department should retain a considerable degree of prosecutorial discretion. The disadvantages that necessarily flow from doing so are outweighed by the advantages of a highly flexible program. But the new Guidelines do reflect, if they do not imtiate, a new era in enforcement policy. Their institutional and procedural impact inust be assessed along with their substance. With these observations and concerns as background, I turn to a more detailed consideration of the guidelines related to horizontal mergers - and of the questions of collusion and efficiency.

\section{B. The Framework of the New Guidelines}

The 1982 Guidelines divide the horizontal merger world into three continents, according to the structure of the unarket in which the inerger occurs: (1) markets that are unconcentrated (postmerger HHI below 1000); (2) inarkets that are inoderately concentrated (postmerger HHI between 1000 and 1800); and (3) inarkets that are highly concentrated (postinerger HHI above 1800). Mergers in unconcentrated markets, inergers in inoderately concentrated markets that produce an increase of less than 100 points in the HHI, and mergers in highly concentrated markets that produce an increase of less than 50 points in the HHI, are not likely to be challenged. Under this "safe harbor" approach soine inergers that were likely to be challenged under the 1968 Guidelines will not be now. ${ }^{30}$ Mergers in highly concentrated inarkets

30. The 1968 Guidelines indicated that challenge was likely even in relatively unconcentrated markets if market shares of the two firms were $5 \%$ each, $10 \%$ and $4 \%$, and so on. 1968 Guidelines, supra note 1, para. 6, 2 TRADE REG. REP. (CCH) at 6884. Under the new Guidelines, no challenge is likely for any inerger, whatever the shares of the firms involved, so long as the postmerger $\mathrm{HHI}$ is below 1000 (described by the Department as approximating a four-firm concentration ratio of 50\%). Guidelines $\$$ III(A), (A)(1)(a), 47 Fed. Reg. at 28,497, 71 CALIF. L. Rev. at 655,656 . For example, assume an industry with 12 firms, 11 having $8 \%$ market sliares and one with a $12 \%$ share. The merger of two $8 \%$ firms would result in a postmerger $\mathrm{HHI}$ of 976 , within the 1982 safe harbor provision, but subject to challenge under the 1968 Guidelines. The difference is seen more clearly in the 1982 Guidelines' statement that the Department is not likely to cluallenge a merger with a postunerger $\mathrm{HHI}$ of 1800 , where the increase in the HHI is less than 100 points. Id. $\$ \mathrm{III}(\mathrm{A})(1)(\mathrm{b}), 47 \mathrm{Fed}$. Reg. at 28,497, 71 CALIF. L. REv. at 656. The increase is derived by multiplying the market shares and doubling it. See id. $\S \mathrm{III}(\mathrm{A})(1)$ n.30, 47 Fed. Reg. at 28,497 n.30, 71 CALIF. L. REV. at 656 n.30. Assune an industry in which 8 firms have $12 \%$ cach, and one firm has $4 \%$. Under the new Guidelines, a merger between the $4 \%$ firm and any other would not be challenged; under the 1968 Guidelines, it would be. 1968 Guidelines, supra note 1, para. 5, 2 TRADE REG. REP. (CCH) at 6884. These hypothetical examplcs (which coine out as they do because the firms are of relatively equal size), suggest that even without expanded market definitions there is a significant variation between the two sets of Guidelines.

It is harder to coinpare the 1982 Guidelines with decided cases, even assuming the inarkcts were properly defined, because available data may not permit HHI calculations. Clearly Von's Grocery and Pabst would not have been brought under the new Guidelines (assuming the aggre- 
which produce an HHI increase of 100 points are "likely" to be challenged.

At these "high" and "low" ends, the Guidelines are formulated in simple numerical terms, although the calculation is complicated soinewhat by use of the HHI measurement. I should note that the use of the $\mathrm{HHI}$ as the measure of concentration is controversial. It may overemphasize the disparity in size among firms in the market, in the sense that disparity, while a relevant factor with respect to collusion, is less significant than the squaring of inarket sliares called for by the index would indicate. ${ }^{31}$ But this question aside, market definition will be the battleground in deciding when these concentration-based standards apply. ${ }^{32}$

The 1982 increases in the imitial, low-end thresholds at which suit may be filed are relatively modest on their face. They are, however, greater than a simple numbers comparison might suggest, since the broadened market definitions envisioned by the Guidelines often reduce market shares. Even with this caveat, though, the new toleration of some smaller mergers that were within the "challenge" range of the 1968 Guidelines is consistent with current economic thinking, and relatively uncontroversial. The ability to collude successfully is not likely to be affected by mergers within these "safe harbor" provisions, and some such mergers are likely to be efficiency creating. The specific numbers utilized in the new Guidelines can be mitpicked; there is no consensus on the point at which the absence of anticompetitive effects is clear, ${ }^{33}$ and there probably never will be. But in probability terms,

gate 4.5\% share in Pabst was correct). For calculations, see 4 P. AREedA \& D. TuRNER, supra note 2, ๆ 909, at 34-51, listing 94 recent horizontal merger cases, with market shares for each party, in descending order based on aggregated market shares. If my calculations are correct, at least the last 29 cases in that listing (many of which were held unlawful) would not have been brought under the new Guidelines, since none increased HHI by 100 points.

31. See 4 P. AREedA \& D. TuRner, supra note 2, ๆ 913, at 76, 79. Disparity in size is a relevant factor in assessing the likelihood of collusion. Sinall fringe firms confronting several inuch larger firms are pricetakers of little relevance to the price-setting process. But the HHI may exaggerate the effect of disparities.

32. This was also true under the 1968 Guidelines and in court, where inarket definition has been the name of the game. The market definition standards of the new Guidelines are no less precise than those of the 1968 Guidelines, although they are more expansive and raise significant issues of workability. Given the difficulties of market definition, is the complexity of the balance of the Guidelines even relevant? Since counsel must already consider a variety of alternative markets, the Guidelines nay appear to be of little use anyway. But some inarkets are relatively clear. And even if not, consideration of a wide range of other factors makes the process slower and inore costly, with outconnes even inore difficult to predict.

33. Space does not permit an examination of all relevant economic studies. Generally, nost studies seew to agree that interdependent pricing is highly unlikely when the number of sellers exceeds 10 to 12 . Some would put the number lower. Express collusion is possible with more sellers, but the cartel will be fragile and more readily detected. See generally 4 P. AREEDA \& D. TURNER, supra note 2, If 910, at 57-58; F. SCHERER, InduSTRIAL MARKET STRUCTURE AND ECO- 
the new Guidelines are surely rational.

Criticism of the raising of the low-end threshold levels is not likely to be based on economic analysis, but upon either an alleged departure from existing judicial interpretations of section 7 (i.e., that the Department is refusing to enforce "the law"), or on the Departinent's unwillingness to incorporate noneconomic factors into its enforcement policy. To a degree, these sane criticisms can be directed toward the 1968 Guidelines. A good case can be made for the view that the 1982 Guidelines depart from contemporary judicial rulings only slightly more than the 1968 Guidelines departed from similar rulings of their time. The 1968 horizontal merger thresholds were not as low as those in Von's Grocery, ${ }^{34}$ and the vertical merger thresholds were not even close to the percentages relied upon in finding a violation in Brown Shoe. . $^{35}$

The present Guidelines should be ineasured agamst more recent decisions, not agamst all of the decisions of the 1960's. While the government in recent years has successfully challenged acquisitions where the market shares have been well within the "safe harbor" provisions of the 1982 Guidelines, ${ }^{36}$ the "law enforcement" issue is similar to that presented in 1968. The same may be said about the Department's unwillingness to factor noneconomic considerations into the Guidelines. The 1968 Guidelines placed no independent reliance on such factors, even though some of the early decisions under amended section 7 appeared to do so. ${ }^{37}$ In sum, while these criticisms may be valid, given the assumptions on which they are predicated, they are not peculiarly applicable to the 1982 Guidelines.

The near absolute presumptive rule applied by the Guidelines at the high end of the scale (HHI of 1800 or above) presents a different question. For those who beheve that concentration short of single firm monopoly is bemign, that tacit collusion is virtually nonexistent and

NOMIC PERFormanCE 175-76, 199 (2d ed. 1980). Recent studies are carefully summarized in P. Pautler, supra note 17. The major disagreement is not whether mergers with an aggregate share of $10-12 \%$ should not be challenged, but at what point larger mergers should be.

34. Von's Grocery, 384 U.S. at 272.

35. Brown Shoe, 370 U.S. at 323-34.

36. The Guidelines indicate that the Department is not likely to challenge any merger with an HHI under 1800 that does not mcrease the index by at least 100 poimts. Guidelines $\S \operatorname{III}(\mathrm{A})(1)(\mathrm{b}), 47 \mathrm{Fed}$. Reg. at 28,497, 71 CALIF. L. REv. at 656. Among more recent successful cases that would not meet this standard, at least under the market definitions used by these courts, are American Gen. Ins. Co., 89 F.T.C. 557, 559 (1977), remanded on procedural grounds, 589 F.2d 462 (9th Cir. 1979), dismissed following divestiture, 3 TRADE REG. REP. (CCH) I 21,816 (Apr. 21, 1981); Liggett \& Myers, Inc. v. FTC, 567 F.2d 1273 (4th Cir. 1977); Beatrice Foods Co. v. FTC, 540 F.2d 303 (7th Cir. 1976). Among recent cases brought by the Department within these ranges are United States v. CBS, 1982-1 Trade Cas. (CCH) I 64,478 (S.D.N.Y. 1981) (consent decree); United States v. Tracinda Inv. Corp., 477 F. Supp. 1093 (C.D. Cal. 1979) (complaimt dismissed).

37. See supra note 26. 
that express collusion can generally be detected and eliminated through prosecutions under section 1 of the Sherman Act, ${ }^{38}$ virtually no presumptive rules are justified, either as a guide to the exercise of prosecutorial discretion or as a basis for judicial decision. For those who subscribe to this view, the Guidelines go too far in pronouncing that the Departinent is "likely" to challenge mergers in inarkets where the inerger increases the HHI by 100 or more points without regard to additional factors other than the failing company defense.

I do not share this view. Nor do others in the field. ${ }^{39}$ While the vigorous debate over the effects of high concentration on output and prices contimues, there is sufficient evidence that tacit collusion can and does occur to justify a pohicy directed toward structures that facilitate such collusion, particularly given the preventive purposes of section 7 and the difficulties of undoing established high market concentration. ${ }^{40}$ Moreover, since exphicit collusion is more likely to occur and far easier to conceal when concentration is high, the Guidelines' presumptive approach to highly concentrated inarkets is justified on the basis of explicit collusion alone.

A inore difficult question is whether the Guidelines should utilize the same presumptive approach for inergers im markets that are soinewhat less concentrated. While the Guidelines use relatively simple numerical HHI indices for the low and high ends of the concentration-market share spectrum, the Department's treatment of mergers in the moderately concentrated zone (HHI of 1000 to 1800), and certain sinaller mergers in the highly concentrated zone, is far more coinplex. It would not be far off the mark to characterize the horizontal merger provisions as guidelines for the low and high ends, with an essay in the middle. Like most essays, it tells us a great deal about the thought processes of the author. What it reveals, more than anytling else, is uncertainty and, on its face, a good deal of caution. The words are tentative; the variables are many and the weight to be given each variable is virtually undefined. Any determination of the Department's likely response to a proposed merger will be time consuming, for a great deal of data will be necessary, and will require close judgment calls. Also, of course, counsel's analysis, however careful, will be reliable only if it matches the Department's own judgment calls. The Guidelines, as to the imddle zone, are an invitation to talk, with some advance indication of the agenda.

38. E.g., R. BORK, supra note 9, at $183,221$.

39. See 4 P. AREEDA \& D. TURNER, supra note 2, II 910-11, at 54-62; R. Posner, supra note 9, at 111-13. Posner would prefer that "tacit collusion" be treated as a violation of section 1 of the Sherman Act, obviating the need for a horizontal merger policy like that of the Guidelines, but does not believe the courts will treat tacit collusion as he suggests.

40. R. POSNER, supra note 9 , at $62-71$. 
The "multivariable" analysis applies to all mergers im markets with a postmerger HHI between 1000 and 1800 that increase the index by 100 points or more, as well as those im highly concentrated markets (HHI over 1800) that increase the index by 50 to 100 points. ${ }^{41}$ In the former case, the Department is "more likely than not" to challenge the merger, but will take into account the actual postmerger concentration and the increase therem, and a range of additional factors. As to the latter case (smaller mergers im more concentrated markets), the Department does not estimate the likelihood of challenge; it states only that its decision will be based on the same concentration and other factors. At the outset, then, in this middle area the Department will utilize an undefined sliding scale based upon concentration and market shares of the merging parties.

The first additional factor to be evaluated is ease of entry, which is to be considered for all mergers. In the words of the Guidelines, "[i]f entry . . . is so easy that existing competitors could not succecd in raising price for any significant period," mergers in that market are not likely to be challenged. Ease of entry will be evaluated by reference to the likelihood of significant entry in response to a nontransitory price increase, which in turn will be based, "as a first approximation," on the degree of entry likely to occur within two years of a hypothetical 5\% price increase. Objective factors related to entry are referred to by footnote. The most curious feature of this provision is that, having indicated the method for determining "how mucli" entry is likely to occur,

41. The Guidelines provide that, without regard to these standards, the Department is likely on the basis of structural data alone to challenge any merger of a firm holding $1 \%$ or more of the market with the leading firm in the same market, if the leading firm has at least $35 \%$ of the market and is twice the size of the next largest firm. Guidelines $\$ 111(A)(2), 47$ Fed. Reg. at 28,497, 71 CALIF. L. REv. at 657. Such a merger will increase individual firm dominance without regard to collusion. Id., 47 Fed. Reg. at 28,498, 71 CALIF. L. REv. 657. In contrast, the 1968 Guidelines contemplated challenge at inarket shares of $25 \%$ and $1 \%$. 1968 Guidelines, supra note 1, para. 6,2 TRADE REg. REp. (CCH) at 6884.

The leading firm provision in the 1982 Guidelines reflects the approach in United States v. Aluminum Co. of Am. (Roune Cable), 377 U.S. 271 (1964), where the Court condemned a merger on the basis of $27.8 \%$ and $1.3 \%$, with the explanation that even slight concentration increases cannot be permitted when concentration is already high. Although the result is correct, the court's rationale is open to question, since, as the Guidelines note, the issue of market dominance relates less to collusion than to individual firm market power. Guidelines $\$ 111(A)(2), 47$ Fed. Reg. at 28,498, 71 CALIF. L. REv. at 657 . Moreover, mergers covered by this provision are not likely to increase the efficiency of the dominant firm, and the smaller firm will have a number of other merger partners available. Given the preventive bias of $\$ 7$, however, I would lower the challenge percentage of the larger firm to $30 \%$; even with this lower figure, real efficiencies are not hikely to be impaired.

What of the case where the dominant firm's market share is $35 \%$ or more, but not twice that of the next largest firm? Assume the next firm has a market share of $25 \%$. In this situation, any postmerger HHI would exceed 1800 , and the Department would be likely to challenge any merger between it and a firm with $2 \%$ or more of the market. The leading firm proviso is simply an override on the Guidelines' other structural standards. 
there is no indication of "how much" is necessary to prevent coinpetitors from raising prices. ${ }^{42}$

Assuming that entry is not "easy," a variety of other factors will be considered ${ }^{43}$ They fall into four categories: (1) product and sales characteristics; (2) market information and buyer characteristics; (3) conduct of firms in the market; and (4) measures of market performance. The first category includes the homogeneity of the products in the market (where the product is completely homogeneous, challenge is "more likely"), the proximity of next-best substitute products and sellers, and, in the case of differentiated products, the actual patterns of competition between particular firms. The second category encompasses the availability to firms in the market of detailed information about specific transactions (which facilitates collusion and thus makes challenge "more likely") and frequent, regular and small sales (which for the same reason will inake challenge "more likely"). The third category is comprised of a history of past collusion, and a variety of specific practices, including inandatory delivered pricing and price exchanges, along with the determination that the acquired firm has been "an unusually disruptive and competitive influence." The presence of any of these circumstances makes challenge "more

42. The Guidelines treat entry by firms with the ability to produce the relevant product by utilization of their existing production facilities and distribution systems as part of the market definition process. Guidelines $\$ 11(B)(1), 47$ Fed. Reg. at 28,495, 71 CALIF. L. REv. at 652. Consideration of entry by other means is covered by this additional provision.

There is disagreement over the independent consideration of entry barriers in merger cases. Areeda and Turner would confine consideration to cases where aggregated market shares are below $20 \%$ and low barriers have been shown by relatively recent and frequent new entry. $4 \mathrm{P}$. AREEDA \& D. TURNER, supra note 2, 1 907, at 25-26. Requiring an assessment of entry barriers "would greatly imcrease the uncertainty, if not the indeterminancy, of most merger cases." Id. I 917, at 87. Morcover, the presence of low entry barriers suggests only that anticompetitive effects are not as substantial or enduring as wonld be the case if barriers were higher, but does not eradicate all such effects. Id. Posner wonld apparently not take entry barriers into account, on practical grounds. R. PosNER, supra note 9, at 59. The approach taken by the Guidelines also has support. See, e.g., Wentz, Mobility Factors in Antitrust Cases: Assessing Market Power in Light of Conditions Affecting Entry and Fringe Expansion, 80 Mich. L. REv. 1545 (1982).

Apart from practical difficulties of proving entry barriers, and measuring their height, economists do not agree over the basic concept. See id. at 1560-66. The Guidelines try to avoid these difficulties by only addressing ease of entry in response to a hypothetical price increase.

43. One of the factors not considered is the presence of a trend toward imcreased concentration in the market, a factor emphasized in a number of decided cases, e.g., Brown Shoe, 370 U.S. at 332, as well as in the 1968 Guidelines, see, e.g., 1968 Guidelines, supra note 1, para. 7, 2 TRADE REG. REP. $(\mathrm{CCH})$ at 6884 . The relevance of such a trend has never been clearly explained. If concentration has been increasing as a result of internal expansion, greater size may be needed for efficiency reasons. In this case, a less restrictive merger policy is called for, since the trend will continue in any event and prohibiting small mergers may make it difficult for small firms to achieve economies. Even if the trend is the result of inergers, the competitive impact of a given merger may be judged by reference to concentration levels at the time, but how such concentration came to be hardly seems relevant. See 4 P. AREEDA \& D. TURNER, supra note 2, I 914, at 82. 
likely." ${ }^{44}$ Fourth, the Department will consider whether the market is performing noncompetitively, which would make challenge "more likely." Factors in these four categories "are most likely to be important where the Department's decision . . . is otherwise close." 45

Finally, in these midzone cases, as with all mergers, the Department will recognize an efficiency defense only " $m$ extraordinary cases," and then in limited circumstances and "otherwise close cases." The failing company defense will save otherwise anticompetitive mergers in soine cases, although the Guidelines circumscribe the defense narrowly. In sharp contrast to the provisions with respect to the factors to be appraised in determining anticompetitive effects, the Guidelines' language describing defenses is brief, precise, and only slightly different from that of the 1968 Guidelines. The contrast is not accidental; if the defenses were inore flexible and expansive, the presumptive rules could be simipler, a point discussed more fully below.

Even a cursory examination of the midzone guidelines provokes obvious questions. First, if the guidelines are read negatively, they suggest that possibly the Department inay not challenge mergers of substantial size. Whether or not this is wise pohicy, is it too great a departure from contemporary legal standards to be justified?

The zone in which suit may not be filed encompasses all mergers in markets with Herfindahl indices from 1000 to 1800 , and mergers above that which increase the HHI less than 100 points. The Guidelines suggest that the $1000-1800 \mathrm{HHI}$ range is roughly equivalent to four-firm ratios ranging from $50 \%$ to $70 \%$. But these numbers are not always comparable with such ratios in the 1968 Guidelines or in most decided cases, smce the expanded markets contemplated by the Guidelines in nost cases will reduce market shares. Moreover, with the use of the HHI, significant mergers in markets with postmerger four-firm concentration ratios well above $70 \%$ may be permitted. For example, suppose a market in which three firms have $20 \%$ market shares, one firm has $15 \%$, and five firms have $5 \%$ each. A merger between the $15 \%$ firm and a 5\% firm would result in a four-firm concentration ratio of $80 \%$ and an HHI of 1700 . Under the 1982 Guidelines, such a merger

44. One of the interesting side effects of this approach may be that a firm interested in merger as part of its strategic planning will have soine incentive to alter its conduct to elininate the mclusion of these factors in merger analysis. For exainple, a firm inight break a pattern of mandatory delivered pricing, or price exchanges, for this reason. While such behavioral changes seem unlikely, the Guidelines do provide some incentive in that direction and could, therefore, have an additional procoinpetitive effect.

45. Presuinably, factors inaking challenge "more likely" will be of greatest relevance when postmerger HHI levels are at the lower end of the inidzone (1000 to 1400$)$, and their absence, if relevant at all, would be of importance at the high end (i.e., closer to 1800). For example, if the $\mathrm{HHI}$ is 1700 but the product is very heterogeneous, challenge is not likely. The Guidelines suggcst a kind of sliding scale based on a combination of structural data and these additional factors. 
could be permitted. In the highly concentrated zone, a merger between a firm with a $10 \%$ market share and a competitor whose market share was $4 \%$ could pass without challenge. These statistical recitations do not establish that the Department's position lacks substantive merit. They do reveal the possibility of a substantial departure from the 1968 Guidelines, ${ }^{46}$ and from relatively contemporaneous judicial decisions condemning horizontal mergers in these ranges without using the multivariable analysis employed by the Guidelines. ${ }^{47}$ Whether the Departinent actually will challenge any, some, or virtually all midzone mergers is uncertain, but the "law enforcement" issue discussed earlier clearly is raised.

It is clear that all of the product, conduct, and behavioral variables

46. The 1968 Guidelines state that in less concentrated markets the Department would ordinarily challenge any merger where the acquired firm has $5 \%$ of the market and the acquiring firm has 5\% or more. 1968 Guidelines, supra note 1, para, 6, 2 TRADE REG. REP. (CCH) at 6884 . In highly concentrated markets, challenge was likely when a firm with $4 \%$ was acquired by a firm with $4 \%$ or more. Id. para. 5, 2 TRADE REG. REP. (CCH) at 6884 . Thus, the deviation between these figures and the upper levels of the midzone of the 1982 Guidelines is substantial.

47. If one believes that the Department will bring no cases below the $1800 \mathrm{HHI}$ level, and only cases above that level where the HHI increase is above 100-that where the Guidelines specify use of a multivariable analysis they contemplate no suit-the Guidelines reveal a marked departure from judicial standards, a departure even greater than may appear because of the expanded markets likely to be utilized. Even in United States v. General Dynamics Corp., 415 U.S. 486 (1974), the last word from the Supreme Court on the subject, the Court was prepared to accept the government's statistical showing based on market shares which do not reflect an $\mathrm{HHI}$ increase of 100 in a market with a four-firm concentration ratio under $70 \%$ as sufficient to make out a prima facie case. $I d$. at 496 . There have been a number of post-General Dynamics cases finding violation based upon data falling short of the Guidelines' high-end threshold level. E.g., Marathon Oil Co. v. Mobil Corp., 530 F. Supp. 315 (N.D. Ohio), affd, 669 F.2d 378 (6th Cir. 1981), cert. denied, 102 S. Ct. 1490 (1982); United States v. Amax, Inc., 402 F. Supp. 956, 958-59 (D. Conn. 1975).

This comparison is inapt, however, for there is little reason to believe that under the multivariable analysis utikzed for midzone mergers no cases will be filed. The degree of departure from present judicial standards is difficult to judge, for a number of post-General Dynamics cases have approved mergers where the structural data was sufficient to make out a prima facie case, relying upon other factors. There is clearly disagreement over the meaning of General Dynamics. Some courts have interpreted the decision strictly, and continued to place primary reliance on structural data. See, e.g., Liggett \& Myers, Inc. v. FTC, 567 F.2d 1273 (4th Cir. 1977). Others have read it more expansively, suggesting analysis of a wide range of factors the presence of which will rebut a statistical case. See Kaiser Aluminum \& Chem. Corp. v. FTC, 652 F.2d 1324, 1332-40 (7th Cir. 1981). These inquiries have not ranged as broadly as the Guidelines. Several cases have focused directly on the future competitive potential of the acquired firm. See, e.g., Lektro-Vend Corp. v. Vendo Co., 660 F.2d 255 (7th Cir. 1981), cert. denied, 455 U.S. 921 (1982); United States v. Tracinda Inv. Corp., 477 F. Supp. 1093 (C.D. Cal. 1979). Several recent cases have emphasized ease of entry, a factor seldom considered previously, in upholding challenged mergers. See, e.g., FTC v. Great Lakes Chem. Corp., 528 F. Supp. 84, 90 (N.D. Ill. 1981); Whittaker Corp. v. Edgar, 535 F. Supp. 933, 950 (N.D. Ill. 1982). Conversely, in Marathon Oil the court put some emphasis on high barriers to entry in finding the merger subject to challenge, 530 F. Supp. at 325-26. In none of these "entry" cases does the court discuss the subject in detail or elaborate standards.

None of these cases fully reflect the analysis of the Guidelines. The decisions expanding the range of inquiry to the greatest extent are in the Seventh Circuit, and may not be followed. 
recited in the Guidelines are theoretically relevant in determining whether a given inerger is likely to contribute to the market power of one or more firms, or to enhance its exercise through implicit or explicit collusion. Consideration of each of these factors in the manner described is rational, at least in the abstract. The theoretical logic of this portion of the Guidelines, complex as it is, seems overwhelining.

The more significant problem is that the tentative language, the large number of variables, and the absence of any indication as to how each is to be weighted, combine to create an impression of complexity, lack of guidance and reservation of a great deal of prosecutorial discretion. This leads to other questions: is this coinplexity necessary to the statement of a rational merger policy, either as a guide to enforcement decisions or as the basis for judicial resolution of particular disputes? Is there a better way?

These questions focus attention on two basic sets of tradeoffs. The first, and most obvious, is that between the benefits derived from the use of general, simple rules directed toward the measurement of anticompetitive effects, and the greater accuracy that might be derived from inore detailed case-by-case analysis of such effects without the benefit of such rules. The second critical set of tradeoffs is between the threat that particular transactions might be anticompetitive, on the one hand, or efficiency creating, on the other. Indeed, a particular transaction might be both. These two sets of tradeoffs are directly related to each other. A presuinptive rule about anticompetitive effects must be accurate for the vast majority of cases and, at a minimum, must not cause substantial harm in those for which it is not. The harm such simplified rules are likely to cause is the impairment of efficiency. The efficiency loss which may occur through mandatory application of a general rule which in a given case does not accurately predict anticompetitive effect is the price paid for the benefits derived when the rule is applied to all other cases. But that loss should be kept to a minimum level, either by the use of rules inore precisely measuring anticompetitive effects or by direct accommodation of efficiency concerns as a defense.

In the middle zone, the Department is either unwilling or unable to rely on generalizations based upon structure and market share data to determine anticompetitive effect, even though it does so at higher concentration levels. The most obvious reason for this is that there is little economic consensus about the concentration levels, however ineasured, at which implicit collusion can or will occur, or about the relationship between concentration and the ease and undetectability of 
explicit collusion. ${ }^{48}$ In the face of conflict among economic studies, the Department declined to pick and choose among them, and instead created an "uncertaimty" zone im which a variety of factors beyond concentration and market share are considered in evaluating anticompetitive effect. When compared to the alternative-using presumptive rules to lower the concentration and market share levels at which challenges will occur without the analysis of other factors-the Guidelines represent a judgment that it is preferable to err on the side of nonintervention.

The Guidelines' cautious approach in the middle zone may be attributed to nothing more than a philosophical bias against government intervention in the marketplace, including the corporate asset marketplace, unless there is a high degree of certainty that anticompetitive effects are likely to result from a proposed transaction. Cases should not be filed unless the statutory violation is relatively clear, particularly simce the burden of proof is on the Department. In the middle zone, economic analysis based solely on structural data is conflicting; thus other factors must be examined before competitive effects can be determined. But more is involved. Some inergers result in economies of scale and imtegration, along with other efficiency savings, that will be lost or deferred if such inergers are successfully challenged. If a merger which offers little likelihood of anticompetitive effect is barred, even though it would increase efficiency, the economic loss is obvious. In other cases, the savings through economies may be great enougl to offset losses inflicted through collusion, even if the merger enhances the likelihood of sucli losses. ${ }^{49}$

\section{Efficiency and the New Guidelines}

This brings ine, somewhat circuitously, to the treatment of real efficiencies which may be created through merger, a central issue in the fornulation of inerger policy. One possible approacli is to ignore effciencies altogether. Section 7 speaks only of anticompetitive effects, and it can be contended that Congress already has drawn the balance by prohibiting any merger which increases narket power or the likelihood of its exercise, whatever the economic tradeoffs. Language in Brown Shoe $e^{50}$ and the Clorox case $^{51}$ has been interpreted as adopting

48. See supra note 33.

49. In a number of cases, relatively small gains in real economies would more than offiset the losses resulting from the higher prices collusion, express or implied, might cause. See $4 \mathrm{P}$. AREEDA \& D. TURNER, supra note 2, \$940, at 149; Williamson, Economies as an Antitrust Defense Revisited, 125 U. PA. L. Rev. 699 (1977); Williamson, Economies as an Antitust Defense." The Welfare Tradeoffs, 58 Am. Econ. Rev. 18 (1968). See also R. Bork, supra note 9, at 107-10, $219-$ 21.

50. Brown Shoe, 370 U.S. at 344.

51. FTC v. Procter \& Gamble Co., 386 U.S. at 580. 
such an approach. ${ }^{52}$ But unwillingness to permit proof of specific efficiencies in court is not inconsistent with the formulation of general rules accommodating efficiency concerns. ${ }^{53}$ To define competition wholly without regard to firm efficiencies is surely perverse.

But if we are not to ignore efficiencies, how are they to be treated in a system of presumptive legal rules which is founded on the ability to generalize? Can we generalize about efficiencies as well? The new Guidelines do so, rejecting any consideration of efficiency creation except in "extraordimary" cases, on the ground that mergers that permit firms to achieve "available efficiencies" will be permitted under the Guidelines in the overwhelming majority of cases anyway. This approach is basically that of the 1968 Guidelines, which also rejected case-by-case consideration of an efficiencies defense, with much the same explanation.

While the above description suggests that the Guidelines' drafters have found that specific point where anticompetitive effects begin and real efficiencies end, there is no such serendipitous convergence. Some mergers that are impermissible according to the Guidelines are efficiency creating, although as the threshold levels get higher, fewer of such mergers are likely to be challenged. And this is the critical point; the challenge thresholds can be set at higher or lower levels depending upon how treatment of the efficiencies defense is resolved. More simply, mergers could be challengcd at lower threshold levels if there is hitlle risk that by doing so we would be preventing mergers that result in scale economies or other real efficiencies. Yet the lower these thresholds are set, the inore likely it is that such adverse effects will occur, unless (1) a specific efficiencies defense is recognized, and (2) the defense will work when efficiencies are present.

The Guidelines start from the opposite point: there will be no general recognition of an efficiencies defense. And to compensate, threshold challenge levels based upon concentration and market data alone are set high, both in recognition of the "new learning" about the effects of concentration, and out of a fear of impairing the abilities of firms to achieve economies through merger. I suspect that the same thinking explains the "uncertainty" zone. That is, because scale economies may be present-economies that cannot and will not be evaluated in every

52. See, e.g., Schwartz, New Merger Guidelines-Guide to Governmental Discretion and Private Counseling or Propaganda for Revision of the Antitrust Laws?, 71 CALIF. L. REv. 575, 593-95 \& $n .92$ (1983).

53. Per se rules under $\S 1$ of the Sherman Act are designed to accomodate efficiency intcrests, i.e., to avoid the prohibition of conduct which in most instances is efficiency creating, but conduct to which the per se rule is applicable cannot be justified by proof of efficiencies in specific cases. See Continental T.V., Inc. v. GTE Sylvania Inc., 433 U.S. 36 (1977). 
transaction-caution is the appropriate course in evaluating the likelihood of anticompetitive effects. The Guidelines do incorporate much of the new thinking about concentration. But even more important in their formulation, I believe, was contemporary economic analysis of the levels at which scale economies, and other true economic savings, may occur.

The Department's hostility to a specific efficiencies defense is central to the Guidelines. The unwillingness to challenge mergers at lower HHI levels, and the complexity that the Guidelines make necessary for midzone mergers do not stem from fear that recognition of an efficiencies defense would result in allowing the merging parties to escape condemnation through proof of efficiencies that are not likely to occur, or simply through obfuscation of issues. Rather, they stem from the behef that proof of specific economies is so difficult that the defense is no safeguard at all. It is seen as an illusion, which cannot be relied upon to provide any assurance that mergers producing econoimes will go unchallenged. ${ }^{54}$

The concern over the tradeoffs between the prevention of anticompetitive consequences and the encouragement of economies is seen in the Guidelines' provisions addressing anticompetitive effects, but does not explain the Department's hostility to such an efficiencies defense when it is otherwise prepared to challenge a particular transaction. The Guidelines do not require the Department to urge rejection of such a defense in court; they simply refuse to make efficiency a consideration in enforcement decisions. The refusal to consider efficiency arguments at the Department level may, or could, rest on the view that such a defense should be allowed ouly where the parties can carry the burden of proof on the issue where it is most difficult to do so-in the courtroom. But, in iny view, if economies are to be considered in any forum, it surely makes inore sense for the Department to consider efficiencies internally, where they can be handled inore flexibly. Moreover, it seems likely that the Department would contest such a defense in court in any event.

Rejecting an efficiencies defense in cases where increases in concentrations threaten added costs through collusion is justifled, if at all, by still other, practical considerations. With the mitial challenge thresholds raised, the cases where substantial econormes can be achieved only above such levels are likely to be relatively few. The economic savings likely to be generated by sorting out a handful of legitimate cases may be outweighed by the delay and complexity such an approach inevitably would cause. Moreover, if the Department

54. See R. BoRK, supra note 9, at 124. 
were prepared to analyze efficiencies, the deterrent effect of the relatively simple rules for highly concentrated markets would be weakened, since firms would be teinpted to test the Department on the issue.

Apart from these practical difficulties, consideration of an efficiencies defense in cases where inergers would substantially increase the risk of collusion (by hypothesis, the only cases where any defense is relevant) would raise at least two additional questions. First, if the same economies could be achieved through internal expansion or a sinaller merger, without undue delay, and without enhancing the risk of collusion, there may be no economic reason to permit the defense. 55 Note that this possibility also reduces further the number of cases where real economies may be substantially impaired if the merger is prohibited (even though we may not be able to identify in which cases such alternatives are available). Second, efficiency savings must also be balanced against the economic losses of additional collusion, a task surely beyond the ability of most factfinders and, perhaps, beyond our present range of knowledge as well. ${ }^{56}$ The case, then, agaimst consideration of an efficiencies defense is compelling if-but only if-challenge thresholds are relatively high and the number of cases in which real economies might be lost is therefore small.

But despite the apparent logic of the Guidelines' approach to tradeoffs between economies and the costs of collusion, such an approach is not inevitable. Because of the Departinent's anxiety to assure that most efficiency creating mergers are permitted, consideration of a wide range of factors in the "uncertainty" zone may permit mergers that increase the risk of collusion. Even if all such inergers are ultimately challenged, the complexity of the competitive analysis will add institutional and process costs, and make planning difficult. The alternative would be to simplify and reduce threshold levels for the presumptive rules used to determine when challenge is likely, and to permit some form of efficiency defense. Areeda and Turner advocate

55. This is not to suggest that the ability to achieve economies through internal expansion makes consideration of economies resulting from merger irrelevant. Adding new capacity may take far inore time than inerger. If a given firm is below optimal size, expansion may add to total output and lower price. But depending on the likely price, this effect inay deter expansion. Moreover, expansion in the face of declining or even stable demand may simply displace another firm, adding to concentration just as a merger does and suggesting that the merger would not be any more anticompetitive. The effect and likelihood of internal expansion cannot be determined in the abstract. See 4 P. AREEDA \& D. TURNER, supra note 2, I 946, at 160-69, where additional complexities are noted.

56. See R. POSNER, supra note 9, at 112-13. But see 4 P. AREEDA \& D. TuRNER, supra note 2, If 962, at 197-99 arguing that an absolute defense based on a showing of substantial economics of specified types is justified, since (1) achievenent of such economies through internal expansion-likely to occur if merger is barred-is likely to add to concentration and thus perhaps to increase prices to the same extent as the inerger, and (2) substantial cost savings will cause a net gain in consumer welfare, i.e., will more than offset the loss from higher prices, in inost instances. 
this approach, ${ }^{57}$ which deserves comparison with the 1982 Guidelines.

Areeda and Turner would presume illegality based upon aggregated market shares in excess of $13 \%$, regardless of market concentration levels. ${ }^{58}$ While this probably is close to the upper limit of the Guidelines" "safe harbor" zone, it presumes illegahty for most midzone cases, without the examination of the wide range of factors required by the Guidelines. Areeda and Turner would consider ease of entry, but only where aggregate market share is below $20 \% .^{59}$ Factors indicatimg that market shares overstate future competitive position would be utilized to adjust market shares downward. ${ }^{60}$ This relatively simple presumptive rule could be rebutted through use of the failing company defense, or through a narrowly confined efficiencies defense (which interjects a degree of uncertainty back into the analysis). ${ }^{61}$

The Areeda and Turner recommendation is stated very tentatively. ${ }^{62}$ It raises a number of issues that caimot be discussed in detail here. But its approach is strikingly different from the Guidelines', and it challenges fundamental judgments contained in the Guidelines at a number of key points. First, Areeda and Turner reflect a stronger bias toward finding illegality, resolving doubts about the effects of concentration at the lower end of the range of disagreement against inergers. This bias exists, perhaps, in recognition of the preventive purposes of section 7. Indeed, Areeda and Turner would be prepared to set an mitial threshold for challenge at an aggregate market share of $10 \%$ if other

57. 4 P. AREEDA \& D. TURNER, supra note 2, If 907, at 24-25.

58. Id. at $25-26$. If the share of the smaller firm is $2 \%$ or less, illegality will not be presumed unless the aggregated shares are above $18 \%$ to $20 \%$.

The Areeda-Turner proposal utilizes a single aggregated market share standard without regard to current concentration levels, and thus does not rely on concentration ratios or the HHI. Several reasons are given, but most important is that condemnation of still smaller mergers because of high existing concentration would interfere too frequently with the achievement of economies by relatively small firms. Id. $\mathbb{9 1 2}$, at 73 .

59. Id. \ 907, at 26. Areeda and Turner beheve that relatively free entry ("low entry barriers") is a relevant economic concern, but that entry at best changes the magnitude or duration of the adverse effects of concentration. Id. $\nabla 917$, at 85-89. Moreover, assessment of the presence and height of entry barriers would unduly complicate merger litigation. Consideration of entry only for mergers in the $13 \%$ to $20 \%$ aggregated share range, and then only when free entry has been evidenced by frequent new entries, is obviously a compromise. Like the 1982 Guidelines, Areeda and Turner would include outside producers who stand at the edge of static geographic markets, and firms who can shift existing facilities to produce the product in question, in the market definition process. 2 id. II 518 , at $347-48,536$, at 426-31.

60. 4 id. 1907 (c), at 25-26. Primary among these concerns is the inadequacy of one (or both) firm's productive or marketing resources, a recognition of the holding in United States v. General Dynamics Corp., 415 U.S. 486 (1974). 4 P. AREedA \& D. TURNER, supra note 2, I 931, at 133-34.

61. The economies defense would be confined to cases where each merging firm has cost disadvantages of at least 5\%, and available only with respect to plant scale economies, plant specialization with complementary products and "possibly" economies in distribution, research and development, and promotion. 4 P. AREEDA \& D. TURNER, supra note 2, I 939, at 147-48.

62. See id. I 915, at 83 . 
factors such as product heterogeneity and buyer concentration were considered and a full efficiencies defense was recognized. They opt for the higher 13\% threshold in part to avoid the need for assessment of such factors, although even then they would retain a limited efficiency defense. Second, the Areeda and Turner proposal places greater emphasis on the value of simplicity and certainty in merger policy. Their analysis reflects more compromise in the name of generalization than do the Guidelines, particularly in their middle (uncertainty) zone. Third, Areeda and Turner are relatively confident that most real efficiencies are susceptible of proof, and therefore that most efficiency creating mergers which are above the presumptive thresholds will be held lawful. This belief justifies rehance on simple, presumptive rules based only on market share data. ${ }^{63} \mathrm{I}$ believe this third point is critical to the basic differences in approach.

Because the treatment of economies of scale and other efficiencies is central to the formulation of specific presumptive rules, choosing between these alternative approaches (as well as others) is simgularly diffcult. Agreement is lacking on the nature, scope and likelihood of real efficiencies, and generalizations are likely to be little more than educated guesses. ${ }^{64}$ Similarly, the value of certainty and simplicity to the processes and institutions of antitrust is largely a matter of individual judgment. While we all agree that simplicity is a virtue, there is little agreement about the extent of the economic costs we are prepared to endure in its name. And though informed tradeoffs require judgments about those costs, general perceptions of legislative purposes and biases inay well be determinative.

In summary, I, like most others-imcluding, I beheve, Areeda and Turner-have no quarrel with the "safe harbor" provisions of the 1982 Guidelines, nor with a significant raismg of the mitial challenge threshold levels. If economic analysis is to be a major determinant of antitrust policy (as I believe it inust), it dictates these provisions.

What I have called the "uncertainty" zone is another matter. My concern is not with uncertainty or complexity per se, which I find less problenatic with respect to Department enforcement policy than do

63. See id. If 950-52, at 176, 180-81 (plant scale and certain specialization economies). Where proof is thought difficult, as with distribntion and promotional efficiencies, Areeda and Turner would permit a defense based on such efficiencies only im very limited circunstances. Id. III 953-54, at 184-89.

64. It now seems generally agreed that plant scale econounies will as often as not require market sliares of $10 \%$, and, conversely, that not all high concentration is dictated by such economies. See Scherer, Economies of Scale and Industrial Concentration, in INDUSTRIAL Concentration: The New Learnino 16, 23-25, 32 (H. Goldschmid, H. Mann \& J. Weston eds. 1974). Generalization on other than an industry-specific basis is virtually impossible. See generally F. Scherer, Industrial Market Structure and Economic Performance 81-117 (2d ed. 1980). 
many others. But the approach used by the Guidelines may be taken as a signal that few mergers will be challenged below the $1800 \mathrm{HHI}$ level. This level, in my judgment, is both higher than economic analysis dictates, and too great a departure from judicially developed standards. In this sense, the Areeda-Turner approach is more attractive, even though I have more doubt than they about the utility of an efficiencies "defense." W5 Whether my concerns are warranted depends on future events, for it is also true that the Guidelines permit the Department to challenge many, if not most, mergers falling within the uncertainty zone. If the Department finds the Guidelines' mode of analysis too complex, or the necessary data too difficult to obtain, it may come to rely more and more heavily on concentration data alone.

For me, the issue is actual enforcement pohicy, and not the Guidelines. The Department will not manipulate its proposed multivariable analysis to reach results inapposite to the Guidelines. But the number. of factors to be evaluated, the anibiguity of the available data, and the highly judgmental quality of the evaluation and appropriate weighting of each factor could, if coupled witl a general attitude of caution, lead to inaction even though the preventive purposes of section 7 require otherwise. I would feel more comfortable if the "uncertamty" zone's upper limits were lower, at an HHI level closer to $1600 .{ }^{66}$

\section{III The Falling Company Defense}

The Guidelines recognize that in some circumstances an otherwise anticompetitive merger will not be challenged if one of the firms imvolved is "failing." The Guidelines' grudgmg recognition of the traditional failing company defense is tersely stated, in contrast to the discursive provisions dealing with market definition and anticompetitive effects. The Department will recognize the defense only where the allegedly failing firm "probably would be unable to meet its financial

65. See Energy Antimonopoly Act of 1979: Hearings on $S .1246$ Before the Senate Comm. on the Judiciary, 96th Cong., 1st Sess. 794, 797-98 (1979) (statement of Thomas E. Kauper).

66. There is no magic to the 1600 level, any more than there is to the higher 1800 level. Precisely how either of these lines is drawn, utilizing the HHI measurement, is dependent upon disparity in firm sizes. This suggestion simply reflects my judgment that the range in which a multivariable analysis is utilized should be narrowed, and that so long as an HHI increase in the range of 80 to 100 points is also part of the challenge threshold, the cost of impairing efficiency, im the relatively few cases where that may happen, is acceptable.

The Areeda-Turner approach would be preferable except for its rehance on an efficiencies defense, which is beset with proof difficulties, particularly as it might be utihzed in court. The result may well be that truly efficiency creating mergers are held unlawful anyway, while confusion results im upholding some mergers which are not. In terms of enforcement guidelines, however, consideration of efficiencies is not as impractical; at the Department level, their proposal is more in accord with my biases, seems workable, and is more readily understood. 
obligations in the near future," would "probably" not be able to reorganize under cliapter 11 of the Bankruptcy Act, and has made "unsuccessful, good faith efforts" to seek alternative acquisition offers which would keep the firm in the market but offer less anticompetitive potential than the merger proposed. The defense will be recognized only when relevant to competitive concerns, and will not be used to assuage the fear over losses to creditors, shareholders, employees and communities which seems to underlie a number of judicial opinions recognizing the defense. ${ }^{67}$ The Guidelines also express a willingness to apply the defense $m$ the case of a failing division of a healthy company "in appropriate cases." The defense is available in all merger cases, but is of primary sigmificance where the merger is horizontal.

The recited standards are sinuilar to those of the 1968 Guidelines except for the specific reference to reorganization in bankruptcy as a preferable alternative to the acquisition at issue. ${ }^{68}$ The rationale underlying the failing company defense historically has been a curious mix of competitive and noncoinpetitive concerns. In refusing to consider any harm that failure might cause to creditors, shareholders, and tle like, the Guidelines are $\mathrm{m}$ accord with the ascendant view that the only goal of antitrust is economic efficiency, ${ }^{69}$ and in conflict with what appears to be the reasoning of a number of decisions. ${ }^{70}$ Of greater consequence, the Guidelines depart in this area from the legislative purpose reflected in the history of section 7 . But rejection of part of the classic rationale for the defense is not of major consequence, since the standards themselves are consistent with those of the courts, even when

67. The failing company defense was recognized in International Shoe Co. v. FTC, 280 U.S. $291,302-03$ (1930), although the analysis was unnecessary to disposition of the case. The court suggested not only that the acquisition of a failing firm might lack anticompetitive effects, but also that the courts should take into account the impact of failure on shareholders, creditors, employees, and communities. The imphication is that adverse competitive effects should be tolerated to avoid harm to such groups. When $\S 7$ was amended in 1950, the legislative reports indicate that the failing company defense would remain applicable, citing International Shoe. It is this citation in the legislative history which Ieads Areeda and Turner reluctantly to conclude that some weight inust be given to such interests. See 4 P. AREedA \& D. TURNER, supra note 2, $8925 \mathrm{c}$, at 105. Accord R. Posner, supra note 9, at 21 n.14. Conversely, Assistant Attorney General Baxter has sharply criticized this reading of history. See Baxter, Remarks: The Failing Firm Doctrine, 50 ANTITRuST L.J. 247 (1982). Subsequent Supreme Court decisions are not particularly helpful on the point, formulating standards for the defense with little or no explanation. See Citizen Publishing Co. v. United States, 394 U.S. 131, 136-38 (1969); United States v. Greater Buffalo Press, Inc., 402 U.S. 549, 555 (1971); United States v. General Dynamics Corp., 415 U.S. at 507 (where the Court does refer to the need to avert injury to competition and "other losses" if the acquired firm fails). Lower courts liave not addressed the issue with any greater clarity, although they often recite the exposition in International Shoe See, e.g., United States v. Black \& Decker Mfg. Co., 430 F. Supp. 729, 776-78 (D. Md. 1976); United States v. M.P.M., Inc., 397 F. Supp. 78, 95-97 (D. Colo. 1975).

68. Sce 1968 Guidelines, supra note 1, para. 9, 2 TRADE REG. REP. (CCH) at 6884-85.

69. See supra note 26.

70. See supra note 26. 
based solely on competitive concerns. ${ }^{71}$ In competitive terms, recognizing the defense is based on the view that in some cases it may be preferable to keep the acquired firm's assets in the market through an acquisition, even at the risk of increasing market power, than to force the firm to exit. Moreover, the acquisition of a truly failing firm may be viewed as a competitive irrelevance, smce the firm would leave the inarket anyway.

Unfortunately, the analysis is not usually so simple. Exit may im fact be competitively preferable to acquisition by a doininant firm. And evaluation of these competitive arguments requires careful assessment of alternatives. In some instances, the firm can be reorganized and reinain a viable competitive force (although creditors and shareholders may be hurt in the process). In still other cases, an alternative purchaser inay pose a significantly reduced threat of an increase in market power than the proposed merger partner.

Partly because of the paucity of simple answers, there is considerable disagreement over the permissible scope of the failing company defense. Some commentators would apparently recognize no defense at all. ${ }^{72}$ Others would expand it to permit the acquisition of any company or division of a company that, because of factors capable of being objectively measured-such as the threat of insolvency - will cease operations in the absence of an acquisition, subject only to the requirement that no competitively preferable purchaser is available. ${ }^{73}$ The Guidelines take the middle ground, even though the actual statement of the defense is more restrictive than the comparable 1968 provision. While the whole range of issues presented by imminent failure caimot be addressed here, the Guidelines themselves invite several specific observations.

Tradeoffs exist in formulating the failing company defense, though they are not the same as the tradeoffs to be considered in the treatment of efficiencies. If presumptive rules with respect to anticompetitive effect are tied to relatively low threshold levels, virtually any threat of failure may be sufficient to indicate that a merger only slightly above the threshold is not anticompetitive, regardless of alternatives for the failing firm. Conversely, if mergers are challenged only above relatively high threshold levels, the defense, whicls permits the anticompetitive effects these levels imply should be restrictive and available only

71. But see infra note 76.

72. See Baxter, supra note 67 , at 251-52. This does not mean that lack of financial resources could never be a relevant factor in determining anticompetitive effect.

73. The 1982 FTC Statement Concerning Horizontal Mergers suggests such an approach, and thus differs substantially from the 1982 Department Guidelines. See FTC Statement, supra note $11, \S$ V, Trade Reg. ReP. (CCH) No. 546, at 52-54. 
where proof is unambiguous. The Guidelines' restrictive view of the defense is consistent, therefore, with the threshold levels at which Department challenge is likely. And it is not surprising that Areeda and Turner, after recommending presumptive rules based solely on market share data at lower threshold levels, also recommend liberalization of the failing company defense. ${ }^{74}$

The formulation of the defense in the Guidelines tracks that used by the Supreme Court in the Citizen Publishing case. ${ }^{75}$ Whatever else is said, the Department cannot be charged with departing from judicial standards. The mclusion of reorganization in bankruptcy as a preferable alternative, while a departure from the 1968 Guidelines, is part of the formulation in Citizen Publishing. ${ }^{76}$

Nor is the Department's willingness to consider the defense in the case of a failing division, as opposed to an entire company, totally new. The 1968 Guidelines certainly did not preclude the possibility. ${ }^{77}$ In competitive terms the issues are essentially the same, although the fact that the division is part of a larger entity suggests another alternativerehabilitation by the parent--which must be considered. The difficulties of assessing the failure of a division are practical ones. For exainple, the larger entity can manipulate data and arbitrarily allocate costs to give the false appearance of probable failure. That deception is pos-

74. The Areeda and Turner proposal varies the elements of the defense with market shares and concentration ratios. For mergers where one firm's market share does not exceed $5 \%$ and the other's does not exceed $50 \%$ or where their aggregate share is $20 \%$ or less and the four-firm concentration ratio does not exceed $75 \%$ after merger, proof that the acquired firm is failing would be sufficient, standing alone. If one firm's share is $10 \%$ or less, and the others' does not exceed 55\%, or their aggregate share is not in excess of $40 \%$ and the four-firm concentration ratio would be $90 \%$ or less after merger, the defense is available only if the acquired firm is failing and there are no preferable purchasers. Above these levels, a third element-proof that the firm actually faces hquidation-must be satisfied. 4 P. AREeDA \& D. TURNER, supra note 2, I 927, at 113-14.

75. Citizen Publishing Co. v. United States, 394 U.S. 131, 136-38 (1969).

76. Some will contend that the Guidelines' insistence that the firm "probably not be able to reorganize successfully under Chapter 11 of the Bankruptcy Act," Guidelines $\S$ V(B), 47 Fed. Reg. at 28,502, 71 CALIF. L. REv. at 665-66, imposed a standard beyond those judicially imposed. The bankruptcy reference in Citizen Publishing Co. has not been repeated in other Supreme Court decisions. See supra note 67 . The incorporation of such a requireinent has been criticized. See 4 P. AREEDA \& D. TURNER, supra note 2, \ 926, at 106-12; R. POSNER, supra note 9, at 21 n.14. Posner describes this portion of the decision as "wrong" because it ignores the concern expressed in the legislative history for the protection of creditors and shareholders. Lower courts have disagreed as to whether reorganization prospects must be evaluated. Cf. United States v. M.P.M., Inc., 397 F. Supp. at 96-97 (reorganizatiou prospects do not constitute an additional element of the failing company defense, but only an alternative to the "no other prospective purchaser" requireinent) with United States Steel Corp. v. FTC, 426 F.2d 592, 608-10 (6th Cir. 1970) (reorganization prospects must be considered under the defense). See also United States v. Black \& Decker Mfg. Co., 430 F. Supp. 729 (D. Md. 1976).

77. See 1968 Guidelines, supra note 1, para. 9, 2 Trade Reg. ReP. (CCH) at 6885 (Department will consider the defense with respect to a failing division "only in the clearest of circumstances."). 
sible, however, should not preclude consideration of cases where it has not taken place. The inclusion of the failing division within the scope of the defense is also required in the interest of candor. Whatever the Department publicly says, it has long considered division failure on an ad hoc, unsystematic basis. Continuation of that policy is precisely what the Guidelines imply with their vague reference to an "appropriate case."

The formal statement of the failing company defense is striking for its brevity and precision. The same may be said with respect to the efficiencies defense. Both provisions stand in sharp contrast to the inore expositive language used elsewhere in the Guidelines. Unless things have changed dramatically over the past four or five years, this apparent precision seems less than candid. The Department informally has decided not to challenge mergers because of likely failure or cessation of operations, even where not all of the Guidelines' criteria have been satisfied. The same, to a lesser degree, may be said of economies of scale and other efficiencies.

This informal consideration of sucl factors may not continue. But if it does, why do the Guidelines not say so? One explanation may be the Department's fear that what it says in the Guidelines may be used agamst it in the courtroom. Whatever its informal practice, it does not want to preempt its arguments at trial. In this instance, the Guidelines may have been drawn with an eye toward the courtroom, rather than exposure of the enforcement process. Neither do I behieve that the Department wants to invite parties to raise such issues, even at the Department level.

Most antitrust observers, especially those not involved directly in the enforcement process, tend to view the failing company defense as a bit of esoterica, a kind of footnote that must be included in any description of inerger policy but that is of little real consequence. If my own experience is any ineasure, the opposite is true. The defense, or something akin to it, is frequently raised before the Department. Evaluation of these arguments is something of an institutional nightmare, particularly with respect to the alternative purchaser requirement.

Consider the case of Company $\mathrm{A}$, which wants to acquire Company B. B is allegedly failing. That contention alone is difficult to evaluate. ${ }^{78} \mathrm{~B}$ wants to be acquired by $\mathrm{A}$, and $\mathrm{A}$ usually is willing to pay a relatively higls price. It is in the very case where the merger would increase A's market power, and is subject to challenge absent the defense, that the buyer (A) is most likely to offer a premium. B has a

78. See generally 4 P. AReedA \& D. TURNER, supra note 2, ff 926, at 106-12. The time pressures discussed subsequently in the text frequently aggravate the difficulty of making this determination. 
vested interest in having $A$ as its merger partner, simce it is unlikely to obtain a premium elsewhere; it does not want to find a competitively preferable alternative purchaser. At the same time, $B$ is required to make a good faith effort to locate one. B has a strong mcentive to create the appropriate "record" while also assuring that no other buyer coines forward. The record that B presents to the Department reveals that a number of prospects were contacted, but the criteria employed in selecting them will remain unclear. The record will not reveal, however, what B told firms expressing an interest.

The Department is well aware of B's motivations and will attempt to cheek with each prospect who expressed an interest, as well as others. But its questions to third parties relate to the hypothetical imterests of firms that lack detailed knowledge about Company B. Moreover, timing is now critical. B advises the Department that bankruptcy is but days away. If bankruptcy proceeds, the very result which the defense is designed to avoid will occur. The mere filing of bankruptcy papers, and accompanying disclosure of the coinpany's true condition, will cause distributors to flee, key personnel to seek employment elsewhere, and so on. Moreover, any alternative purchasers coming forward after bankruptcy papers are filed will offer only a distress price.

The Department is now in a no-wm position. It cannot adequately assess alternative prospects withm the time limits prescribed by the parties, unless it is prepared to challenge B's assertion that bankruptcy is imminent. If it calls the bluff and is wrong, bankruptcy proceedimgs will begin: what the defense is designed to prevent may occur, without any final determination that the failing company defense was unavailable. The Department may indicate that it will challenge the transaction unless B is publicly offered for sale for some period, and no preferable purchaser appears. But the Department cannot forestall bankruptcy. The disclosures which accompany such a public offering are likely to damage the company as an ongoing busmess and cause a rapid decline in its value. Consequently, the Department may decide not to try to enjoin the transaction, although it may later challenge the transaction in the calmer period that follows consummation. B has what it wants. It has avoided an injunction. It lias bought time. The remedy would now nornally be divestiture. $B$ is off the hook, smce divestiture does not norinally simply reconstitute $B$ as it was prior to its merger with A. ${ }^{79}$ And it is off the hook because it can control timing by arriving with a predetermined merger partner just as its failure is imminent.

79. Divestiture will generally involve sale of the stock or assets of firm B to yet another buyer. Rescission has been sought by the Department on occasion, but would be of little utility where the original seller (Company B) no longer exists. See Kauper, Antitrust Relief and Innovation, 50 ANTITRUST L.J. 71, 77-79 (1982). 
This scenario is neither unlikely nor hypothetical. I have lived through it more than once. It is presented here for several reasons. It explains why, in soine cases, the Department fails to challenge some mergers that do not meet the criteria of its own Guidelines ${ }^{80}$-it must make poorly educated guesses and play hunches. The scenario may also explain why the Department is less than eager to disclose its enforceinent processes-there is hittle desire to invite disputes such as that presented above. Finally, it suggests that those who urge a considerable relaxation of standards in order to permit the merger of any financially troubled firm that is likely to cease operations with any available purchaser-in the absence of preferable alternatives-do not recognize all of the practical difficulties that are posed by their proposal. These problems arise primarily at the Department level, or in actions for preliminary injunctions. After consummation, the same issues presented in the courtroom are more inanageable. The only remedy, however, is likely to be divestiture, which is frequently inadequate and ineffective.

The Division's position on the failing coinpany defense may be challenged as inconsistent with the legislative history of section 7. And it may in fact not be followed, as it has not been in the past. But given the practical difficulties the defense presents, as well as the fact that only relatively large mergers will be challenged under the Guidelines, rejection of the defense in relatively inflexible terms is appropriate.

\section{CONCLUSION}

The search for relatively simple rules predicated upon generalizations about the likely effects of certain kinds of conduct has been the predominant theme in the development of antitrust doctrime. The forinulation and elaboration of per se rules under section 1 of the Sherinan Act is the most obvious example of the continuing effort to obtam the benefits of simplicity without seriously impairing the accuracy of the judgments required by the underlying statutes. As thinking about types of conduct has changed, per se rules have been abandoned or tailored to combine generalization with more examination of facts in specific cases. ${ }^{81}$

The history of section 7 of the Clayton Act, as amended in 1950, has mirrored this phenomenon. The 1955 Attorney General's Commit-

80. The Department's departure from its own Guidelines does not mean it views its statement of standards as wrong; the data required to apply those standards is simply not available in the relevant time frame.

81. The best example is Continental T.V., Inc. v. GTE Sylvania Inc., 433 U.S. 36 (1977). 
tee suggested a broad ranging, case-by-case inquiry in merger cases. ${ }^{82}$ But since 1955, relying on the proposals of Kaysen and Turner ${ }^{83}$ and the particularly influential work of then-Professor Bok, ${ }^{84}$ the courts have inoved away from such a multivariable analysis in the direction of presumptive rules predicated on market share and concentration data. ${ }^{85}$ The 1968 Guidelines took the same path, in part because the judiciary had already done so. The 1982 Guidelines do not reject this approach, even though they reflect some of the "Rule of Reason" thinking of the 1955 Attorney General's Committee Report. They are an atteinpt to fine-tune the quality of decisionmaking without losing the institutional benefits and the certainty that results from general rules. There is a risk to such efforts; the identification of too many relevant variables may confront the factfinder with more detailed information than he or sle can assimilate, so that the quality of decisioninaking inay decline, while the beneflts of generalization are also lost. Whether the 1982 Guidelines go too far in this respect will depend to a substantial extent on how they are impleinented througl enforcement decisions.

The horizontal inerger Guidelines are a significant intellectual achieveinent. They are a rational response to current economic thinking. The raising of initial thresholds at which challenge is likely is sensible and uncontroversial. Tradeoffs between anticompetitive effects, efficiencies and the impact of firm failure are made intelligently. It is logical to consider ease of entry as courts have already begun to do. The factors to be considered in evaluating inidzone mergers are all relevant to the likelihood of collusion.

Why, then, have the Guidelines created a significant degree of uneasiness? For soine, this discoinfort rests squarely on the degree of prosecutorial discretion retamed by the Department. The flexibility of the market definition process and the multivariable analysis contemplated for midzone inergers are viewed as a mask for inaction-an elaborate intellectual justification for subverting the prophylactic purposes of section $7 .^{86} \mathrm{In}$ its most extreine form, this contention charges the Departinent with something akin to fraud.

In iny judgment, there is no justiflcation for such criticism. Although the Guidelines do allow the Department to retain a good deal of discretion (despite their appearance of scientiflc precision), the De-

82. Att'y Gen's Nat'l Comm. to Study the ANtitrust Laws, Report 125-27 (Comm. Print 1955).

83. C. Kaysen \& D. Turner, Antitrust Policy 132-36 (1959).

84. Bok, Section 7 of the Clayton Act and the Merging of Law and Economics, 74 HARv. L. REV. 226 (1960).

85. See Philadelphia Nat'l Bank, 374 U.S. at 362-66.

86. See Schwartz, supra note 52. 
partment has said what it means, and must be presumed to be acting in good faith to implement the policy as stated. Nevertheless, if the Guidelines' midzone merger provisions prove unworkable because the analysis is simply too complex, relevant data cannot be obtained, or for some other reason, the Departinent inay be forced to rely primarily on the presumptive rules governing either the low or high ends of the zone. This could result in the toleration of large horizontal mergers, and a significant departure from contemporary judicial standards. Consequently, while I would have preferred a somewhat lower upper limit to the middle zone, I beheve it more hikely that the Department will rely on lower threshold concentration levels as the basis for challenges if the consideration of other factors proves either inconclusive or impossible. When the Department asserts that it is "more likely than not" to challenge mergers above an HHI of $1000, \mathrm{I}$ assume it means what it says.

The greatest difficulty with the 1982 Guidelines is their complexity, which imposes obvious institutional and economic costs. Planning will be more difficult. Decisionmaking will take more time. Data collection and analysis will be expensive, in time and dollars. If the Guidelines are ultimately adopted by the courts, these costs will be even greater.

Some effects are less obvious. Second requests under the premerger notification rules will be more common, delaying consummation in inore cases. If, as I believe, the Department is less likely to seek prelimmary injunctions, ${ }^{87}$ the ineffective and inefficient divestiture remedy will be the relief normally sought. Informal guidance from the Department will be sought inore frequently and in more cases, placing the Departinent in the position of redesigning transactions and displacing the inarket as the decisionmaker. Finally, the need to evaluate all relevant factors inay even take factfinders beyond their capabilities, and less accurate decisions may result.

At the moment, these are hypothetical concerns. Moreover, even if some of these effects are likely, their impact cannot be measured. Some are the result of uncertainties inherent in the market definition process. But the risk of adding to these costs should be avoided, where possible. The critical issue is whether the use of a multivariable analysis adds to the accuracy of the ineasurement of anticompetitive effects in a large enough number of cases to warrant the detrimental inpact of added complexity. I have no answer. Nor, I believe, does anyone else. I am satisfied, liowever, that the relevance of the Department's addi-

87. It is also less likely to obtain them, if the courts begin to hold the Department to the standards of the Guidelines. The very complexity of the issues raised is likely to suggest that probability of success cannot be measured in a preliminary injunction hearing but must await full trial. 
tional factors diminishes significantly as the HHI increases, and that the upper threshold-the point at which challenge based on concentration data alone becomes "likely"-could be reduced to the HHI 1600 level without sacrificing the reliability of enforcement decisions.

To all of this I add one final note. Pages have been spent evaluating what the Department says. But given the degree of discretion the Guidelines allow, what the Department actually does is more important. We must all wait and see. 